\title{
Comparison of Type I Diabetes Frequency in Children with Cesarean and Normal Vaginal Delivery
}

\author{
Sezaryen ve Normal Vajinal Doğan Çocuklarda Tip 1 Diyabet Sıklığının Karşılaştırılması
}

\author{
İbrahim Ethem ŞAHİ ${ }^{1}$ \\ (i) 0000-0003-3745-7015 \\ Ceyhan HACIOĞLU ${ }^{1}$ \\ (iD) 0000-0002-0993-6118 \\ Merve ALPAY ${ }^{1}$ \\ (D) 0000-0002-8782-9561 \\ Önder KILIÇASLAN ${ }^{2}$ \\ (D) 0000-0002-9311-006X
}

\begin{abstract}
Aim: The effect of type 1 diabetes mellitus over the world is rising day after day. There are controversial results that may be related to cesarean delivery that has become widespread in recent years and the risk of type 1 diabetes mellitus. In this study, we aimed to investigate the frequency of type 1 diabetes mellitus in children born by cesarean delivery or normal vaginal delivery, considering that there may be an association between mode of birth way and diabetes mellitus.

Material and Methods: The study was organized with 368 children who were diagnosed as type 1 diabetes mellitus between 8-16 ages that applied to the diabetes outpatient clinic in 2019. The patients were grouped according to the mode of delivery. Descriptive data such as age, gender, HBA1c, and BMI were evaluated retrospectively.

Results: The children with type 1 diabetes mellitus, cesarean delivery show $33.2 \%$ more than normal vaginal delivery $(\mathrm{p}<0.001)$. While $9.0 \%$ of children with cesarean delivery had mother's diabetes mellitus, this rate was $5.7 \%$ in children with normal vaginal delivery. Similarly, $5.3 \%$ of children with cesarean delivery had diabetes mellitus in their father, while this rate was $8.9 \%$ in children with normal vaginal delivery.

Conclusion: According to the results of this study, cesarean delivery may have a significant effect on the risk for type 1 diabetes mellitus in childhood either adolescence. Even if parents with diabetes were not included, it was found that cesarean delivery have meaningful relation by diabetes mellitus stimulation. Regarding this, further studies are needed.

Keywords: Cesarean delivery; normal vaginal delivery; type 1 diabetes.
\end{abstract}

${ }^{1}$ Düzce University Faculty of Medicine Department of Medical Biochemistry, Düzce, Turkey

${ }^{2}$ Düzce University Faculty of Medicine Department of Child Health and Diseases, Düzce, Turkey

\section{Corresponding Author Sorumlu Yazar \\ İbrahim Ethem ŞAHIN \\ ibrahimethem71@yahoo.com}

Received / Geliş Tarihi : 04.05.2020 Accepted / Kabul Tarihi : 08.07.2020 Available Online /

Çevrimiçi Yayın Tarihi : 25.08.2020
ÖZ

Amaç: Tip 1 diyabetin dünya üzerindeki etkisi her geçen gün artmaktadır. Son yıllarda yaygınlaşan sezaryen doğum ve tip 1 diyabet riski arasında ilişkili olabilecek tartışmalı sonuçlar vardır. Bu çalışmada, doğum şekli ve tip 1 diyabet arasında bir bağlantı var olduğunu düşünerek sezaryen ve normal vajinal yolla doğan çocuklarda tip 1 diyabet görülme sıklığının araştırılması amaçlandı.

Gereç ve Yöntemler: Araştırmaya 2019 yılında diyabet polikliniğine başvuran 8-16 yaşları arasında olan tip 1 diyabet tanısı konmuş 368 çocuk dahil edildi. Hastalar doğum şekline göre gruplandırıldı. Hastalardan elde edilen yaş, cinsiyet, HBA1c ve BMI gibi tanımlayıcı veriler geriye dönük olarak değerlendirildi.

Bulgular: Tip 1 diyabet tanısı olan çocuklarda sezaryen doğumun normal vajinal doğuma göre $\% 33,2$ daha fazla olduğu görüldü $(\mathrm{p}<0,001)$. Sezaryen ile doğan çocukların \% $\%, 0$ 'unun annesinde diyabet tanısı bulunurken, normal vajinal yolla doğan çocuklarda bu oran $\% 5,7$ idi. Benzer şekilde, sezaryen ile doğan çocukların \% 5,3 'ünün babasında diyabet tanısı bulunurken, normal vajinal yolla doğan çocuklarda bu oran $\% 8,9$ idi.

Sonuç: Bu çalışmadan elde edilen sonuçlara göre, sezaryen doğum çocukluk veya ergenlik döneminde tip 1 diyabet riski üzerinde önemli bir etkiye sahip olabilir. Bununla birlikte, diyabetli ebeveyn olguları dahil edilmese bile, sezaryen ile doğum ve tip 1 diyabet arasında önemli bir ilişki olduğu bulunmuştur. Bununla ilgili olarak, daha ileri çalışmalara ihtiyaç duyulmaktadır.

Anahtar kelimeler: Sezaryen doğum; normal vajinal doğum; tip 1 diyabet. 


\section{INTRODUCTION}

Diabetes mellitus (DM) is one of important metabolic diseases defined as hyperglycemia caused by secretion or activity of impaired insulin (1). Some patients with diabetes might life-threatening experience as acute hyperglycemic attacks, while others may life-threatening experience as acute hypoglycemic attacks for outcome diabetes treatment (2). During disease progression, some complications such as retinopathy, nephropathy, neuropathy, atherosclerosis and gangrene might be seen (3). Diabetes is a common disease whose true prevalence is unknown and the population of patients have diabetes are increasing day by day. While the estimated number of patients were around 380 million in 2014 , this number is expected to reach 592 million by 2035 (4). In the national health and nutrition analysis conducted using fasting blood sugar and oral glucose tolerance test at 2005/2006, and it was determined that the prevalence of diabetes was $12.9 \%$ in individuals under 20 years of age in the United States. This rate of $12.9 \%$ corresponds to approximately 40 million people (5). In a study on pre-diabetes prevalence in adults with diabetes in 2010 in China (6), diabetes was $11.6 \%$ (effected 113.9 million people), and pre-diabetes was $50.1 \%$ (effected 493.4 million people). For classification made in 1979, two main kinds of diabetes were identified: type 1 (insulin dependent, IDDM) and type 2 (non insulin dependent, NIDDM). Among cases of total diabetes, $5-10 \%$ patients with DM are in the type 1 group approximately (7).

Patients often have a sudden onset such as polyuria and rapid weight loss. Patients have insulin deficiency as a result of a problem caused by pancreatic beta cells. The peak incidence occurs in childhood and adolescence. Type 2 group accounts for $90 \%$ of all patients with DM (8). The symptoms in patients are minimal and not prone to ketosis. In this group of patients, insulin concentrations may be normal, decreased or increased. In this form of diabetes, the effect of insulin is generally impaired. It is commonly associated with obesity and weight loss alone can control hyperglycemia. However, many individuals with type 2 diabetes may need dietary intervention, antihypertensive agents, or insulin therapy to control hyperglycemia (9). Although the disease can be seen at a young age, it usually occurs after the age of 40 (8).

Worldwide cesarean delivery is increasing day by day. Scientific progress, social, cultural and legal changes have led to a fundamental cesarean change between patients and doctors (10). Changing risk profiles and previous cesarean births in old primipas may contribute to the increase of the number of cesarean people (11). Despite all these perspectives, cesarean birth has numerous potential complications (infection, organ injuries, blood transfusion need) for mother and baby (12). Apart from the risks during the operation, there are many postpartum complications such as thromboembolism (10). There are various risks (such as uterine rupture, placenta previa) in women who have delivered by cesarean (13). In recent years, it has been observed that there may be some risks (neonatal respiratory distress, allergic rhinitis, pulmonary hypertension, type $1 \mathrm{DM}$ ) in babies born by cesarean section (14-16).

In $1991,15.3 \%$ of all births in Germany were performed by cesarean, while in 2012 this rate was $31.7 \%$ (17). The cesarean rate in Sub-Saharan Africa is 3\%, 31\% in Central America and $32.2 \%$ in the USA $(18,19)$. This elevation can be explained by a rising tendency to avoid risk, obstetric practice adaptation and increased media caution. It was carried out in the European Union in 2000 with 221 cesarean per 1000 live births, this rate increased to 268 per 1000 live births in 2011 (17).

Many studies have investigated cesarean section regarding the threating of type 1 diabetes in childhood. A metaanalysis results involved 16 observational studies showed that there is a potential relationship among higher frequency of cesarean section and an increased risk of type $1 \mathrm{DM}$ (20). In the meta-analysis included 20 retrospective studies, there was a $20 \%$ increasement at childhood-onset type 1 diabetes risky in children giving birth by cesarean section (21). Many studies have researched cesarean and type 1 diabetes, however in some studies, the findings have been incoherent, possibly as a cause of insufficient sampling and limited strength. The aim of this study is to determinate whether a relationship with the risk of type 1 diabetes in children born with cesarean section and normal vaginal delivery.

\section{MATERIAL AND METHODS}

The literature review was done using PubMed and using the keywords "cesarean delivery", "normal vaginal delivery", "mode of delivery", "diabetes mellitus, type 1", "IDDM". The researches carried out mostly belonged to 2007 and before. The data in the patient files of all children who were between 6-18 ages who applied to the Endocrinology outpatient clinic of Düzce University in 2019, were diagnosed with type 1 DM, and their HbA1c value was above $6 \%$, were analyzed retrospectively. Children who have type 1 DM between the ages of 8 and 16 , having a mode of delivery in epicrisis, maternal body mass index (BMI) 20-30 and children with elective cesarean section and normal vaginal delivery were included in the study. The criteria for exclusion are children under the age of 8 and over 16, lack of natal knowledge in epicrisis, children with urgent cesarean delivery and the mother has any chronic conditions. According to the information obtained from the patient files, the patients were separated with two groups as normal vaginal birth and elective cesarean birth. 368 of 1574 patients who contain the inclusion criteria were included in the study. Of the 368 patients, 205 (55.7\%) were male and $163(44.3 \%)$ were female. This study was approved by Düzce University Non-Interventional Health Research Ethics Committee (02.03.2020 and 2020/29) prior to any data collection. In accordance with the Helsinki Declaration Principles, "informed consent" was taken from the patients who participated in the study.

\section{Statistical Analysis}

Descriptive statistics for categorical variables were used as numbers and percentages, and mean and standard deviation (SD) for numerical variables. Pearson chi-square test was used to examine between type of birth and the proportion of children with type $1 \mathrm{DM}$ as well as obstetric features such as the number of parents with diabetes or non-diabetes and sex of the child. Kolmogorov-Smirnov tests were used to determine the suitability of variables for normal distribution. For univariate analyzes between 
cesarean section and normal vaginal birth groups, Student's t-test was used. SPSS 20.0 software was used for statistical analysis, and $\mathrm{p}$ values $<0.05$ were regarded as statistically significant.

\section{RESULTS}

Amongst 368 children with birth way data, 245 were born by cesarean delivery and 123 by normal vaginal delivery. The most cases $(66.6 \%)$ of children with type 1 DM were born by cesarean section. Besides that, $33.4 \%$ of children with type $1 \mathrm{DM}$ were born by normal vaginal delivery. The children who have type $1 \mathrm{DM}$, cesarean section births show $33.2 \%$ more than normal vaginal delivery $(p<0.001)$. There was no statistically significant difference in gender, maternal age and BMI of children with diabetes between cesarean delivery and normal vaginal delivery groups; thus, homogeneity between the groups is provided.

The number of mothers and fathers with diabetes are shown in Table 1 . The number of mothers with diabetes in cesarean birth group $(n=22,9.0 \%)$ is higher compare to normal vaginal birth group $(n=7,5.7 \%)$. However, the number of fathers with diabetes in normal vaginal birth group $(\mathrm{n}=11,8.9 \%)$ is higher than in cesarean birth group $(n=13,5.3 \%)$. When it is evaluated separately according to the type of birth and the diabetes status of the parents, children with type 1 diabetes, whose parents non-diabetes, were common in the cesarean section delivery group $(\mathrm{n}=210,85.7 \%)$ according as vaginal normal delivery group $(\mathrm{n}=105,85.4 \%)$.

\section{DISCUSSION}

We evaluated all children between the ages of 6 and 18 who were admitted to the pediatric type $1 \mathrm{DM}$ outpatient clinic in 2019 year which diagnosis of type 1 diabetes using hospital automation throughput. In accordance with results, the frequency of type 1 diabetes was significantly higher for children born with cesarean birth compared to children born with vaginal birth way. Samuelsson et al. (22) found an increased risk of type $1 \mathrm{DM}$ for children born by cesarean in a study in Norway. However, there was no increased risk for children of non-diabetic mothers, whereas there was an increased risk for cesarean delivery in children born from diabetic mothers. They attribute that increased risk of diabetic mothers to diabetic mothers giving birth more frequently by cesarean. From our

Table 1. Demographic and obstetric characteristics

\begin{tabular}{lccc}
\hline & $\begin{array}{c}\text { Elective } \\
\text { Cesarean } \\
\text { Delivery } \\
(\mathbf{n = 2 4 5})\end{array}$ & $\begin{array}{c}\text { Normal } \\
\text { Vaginal } \\
\text { Delivery } \\
(\mathbf{n = 1 2 3})\end{array}$ & $\mathbf{p}$ \\
\hline Maternal age & $29.50 \pm 4.15$ & $29.3 \pm 1.07$ & 0.599 \\
Maternal BMI & $24.21 \pm 3.77$ & $23.68 \pm 1.94$ & 0.144 \\
HbA1c & $8.52 \pm 2.15$ & $8.14 \pm 1.86$ & 0.096 \\
Gender & & & \\
$\quad$ Male & $102(41.6 \%)$ & $61(49.6 \%)$ & 0.147 \\
$\quad$ Female & $143(58.4 \%)$ & $62(50.4 \%)$ & \\
Parents with DM & & & \\
$\quad$ Mother & $22(9.0 \%)$ & $7(5.7 \%)$ & 0.248 \\
$\quad \begin{array}{l}\text { Father } \\
\quad \text { None }\end{array}$ & $13(5.3 \%)$ & $11(8.9 \%)$ & $105(85.4 \%)$ \\
\hline BMI: Body mass index, HbA1c: Hemoglobin A1c, DM: Diabetes Mellitus &
\end{tabular}

retrospective study, we found that the ascending population of type 1 diabetes in children borned by cesarean section continues when we exclude children with $\mathrm{DM}$ in their family (mother or father).

The increase of the risk of type $1 \mathrm{DM}$ in children born with cesarean was observed in almost all studies conducted in this direction. However, other factors that cause diabetes type 1 in childhood (gestational age, birth weight, maternal age, breastfeeding and maternal diabetes) cause complexity to clarify relationship cesarean delivery and type 1 diabetes.

In a meta-analysis study conducted in 2010, type 1 diabetes was $\% 10$ risk increasement observed in children born with a birth weight over $4 \mathrm{~kg}$ compared to those born with $3-3.5 \mathrm{~kg}$ (23). The findings of the more population study holded by Khashan et al. (24) were consistent with synchronization results of this study. Another study published in 2014, the risk of occurs type 1 diabetes in childhood was found to be $18 \%$ in preterm infants (25). Additionally, Bingley et al. (26) found a strong relationship between high maternal age and an increased risk of developing diabetes in the child.

Cardwell et al. $(15,23)$ found that high birth weight, short gestation period and high maternal age increased the risk of diabetes at child in a meta-analysis conducted over twenty studies. Moreover, when other risk factors (gestational age, birth weight, maternal age, breastfeeding of the baby and maternal diabetes) that were stated to exist for type 1 diabetes were added, a very small augmentation for risk of cesarean delivery was observed. On the other hand, without these factors, cesarean under elective conditions increased the risk of type 1 diabetes by approximately 20\%. Compatible with Cardwell et al. research, when the presence of type 1 diabetes was excluded in the mother or father, we also found that the rate of cesarean delivery among children with type 1 diabetes was significantly higher than the normal vaginal delivery.

Many patients with type 1 diabetes have autoimmune damage mediated by $\mathrm{T}$ cells of pancreatic beta cells, some are idiopathic (27-29). Islet cell cytoplasmic antibodies (30), insulin autoantibodies (31), antibodies to glutamic acid decarboxylase (32), insulinoma-associated antigens (33), zinc transporter ZnT8 (34) are the best-defined autoantibodies associated with type 1 diabetes.

Although some hypothesis (intestinal microbiota, bacterial revelation during pregnancy, perinatal period stress and hygiene) have been suggested in increasing the risk of type 1 diabetes with cesarean delivery, it is not fully understood what the possible offender is. However, the most prominent of these hypotheses is the altered intestinal microbiata. It is thought that intestinal microbiota plays an important drive to stimulate the progress of immune system (35).

Novel studies have indicated that the intestinal microbiota of a child born by cesarean or normal vaginal birth is different (36). In a prospective study, the rate of bifidobacterium and lactobacillus-like bacterial colonization delayed in the cesarean babies of the mother who had antibiotic prophylaxis, and the rate of babies who gave birth in a normal vaginal way in 1 month and 10 days. This study also showed that changes on intestinal flora of a baby born by cesarean would not take less than 6 months (37). 
Beside those in vivo experiments, normal intestinal flora has been shown to have an immunostimulating effect. Mucosal sort $\operatorname{IgA}$ cells are relatively less than immunesupressed animals (38). The fact that babies born with cesarean are relegated high risk of improving type 1 diabetes in childhood compared to children born with a normal vaginal route may be a late-activated immune system due to the difference in intestinal microbiota in these children, or another reason might be investigated (39). Further studies are needed to make etiopathogenic mechanism more clear about the frequency of diabetes and the way of birth.

Conflicts of Interest: The authors declared that no conflicts of interest.

\section{REFERENCES}

1. American Diabetes Association. Report of the expert committee on the diagnosis and classification of diabetes mellitus. Diabetes Care. 1997;20(7):1183-97.

2. Sheetz MJ, King GL. Molecular understanding of hyperglycemia's adverse effects for diabetic complications. JAMA. 2002;288(20):2579-88.

3. Melendez-Ramirez LY, Richards RJ, Cefalu WT. Complications of type 1 diabetes. Endocrinol Metab Clin North Am. 2010;39(3):625-40.

4. International Diabetes Federation. IDF Diabetes Atlas. 6th ed. Basel, Switzerland: International Diabetes Federation; 2013.

5. Cowie CC, Rust KF, Ford ES, Eberhardt MS, ByrdHolt DD, Li C, et al. Full accounting of diabetes and pre-diabetes in the U.S. population in 1988-1994 and 2005-2006. Diabetes Care. 2009;32(2):287-94.

6. Xu Y, Wang L, He J, Bi Y, Li M, Wang T, et al. Prevalence and control of diabetes in Chinese adults. JAMA. 2013;310(9):948-59.

7. National Diabetes Data Group. Classification and diagnosis of diabetes mellitus and other categories of glucose intolerance. Diabetes. 1979;28(12):1039-57.

8. American Diabetes Association. Diagnosis and classification of diabetes mellitus. Diabetes Care. 2014;37(Suppl 1):S81-90.

9. American Diabetes Association. Type 2 diabetes in children and adolescents. Diabetes Care. 2000;23(3):381-9.

10. Stjernholm YV, Petersson K, Eneroth E. Changed indications for cesarean sections. Acta Obstet Gynecol Scand. 2010;89(1):49-53.

11. Belizán JM, Althabe F, Cafferata ML. Health consequences of the increasing caesarean section rates. Epidemiology. 2007;18(4):485-6.

12. Lavender T, Hofmeyr GJ, Neilson JP, Kingdon C, Gyte GML. Cesarean section for non-medical reasons at term. Cochrane Database Syst Rev. 2006;3:CD004660.

13. Silver RM, Landon MB, Rouse DJ, Leveno KJ, Spong CY, Thom EA, et al. Maternal morbidity associated with multiple repeat cesarean deliveries. Obstet Gynecol. 2006;107(6):1226-32.

14. Levine EM, Ghai V, Barton JJ, Strom CM. Mode of delivery and the risk for respiratory diseases in newborns. Obstet Gynecol. 2001;97(3):439-42.

15. Cardwell CR, Stene LC, Joner G, Cinek O, Svensson $\mathrm{J}$, Goldacre MJ, et al. Caesarean section is associated with an increased risk of childhood-onset type 1 diabetes mellitus: a meta-analysis of observational studies. Diabetologia. 2008;51(5):726-35.

16. Brandão HV, Vieira GO, de Oliveira Vieira $T$, Camargos PA, de Souza Teles CA, Guimaraes AC, et al. Increased risk of allergic rhinitis among children delivered by cesarean section: a cross-sectional study nested in a birth cohort. BMC Pediatr. 2016;16:57.

17. Mylonas I, Friese K. Indications for and risks of elective cesarean section. Dtsch Arztebl Int. 2015;112(29-30):489-95.

18. Betrán AP, Merialdi M, Lauer JA, Bing-Shun W, Thomas J, Van Look P, et al. Rates of caesarean section: analysis of global, regional and national estimates. Paediatr Perinat Epidemiol. 2007;21(2):98-113.

19. Stanton CK, Holtz SA. Levels and trends in cesarean birth in the developing world. Stud Fam Plann. 2006;37(1):41-8.

20. Stene LC, Magnus P, Lie RT, Søvik O, Joner G, Norwegian Childhood Diabetes Study Group. No association between pre-eclampsia or caesarean section and incidence of type 1 diabetes among children: a large population-based cohort study. Pediatr Res. 2003;54(4):487-90.

21. Taplin CE, Craig ME, Lloyd M, Taylor C, Crock P, Silink M, et al. The rising incidence of childhood type 1 diabetes in New South Wales, 1990-2002. Med J Aust. 2005;183(5):243-6.

22. Samuelsson U, Lindell N, Bladh M, Åkesson $\mathrm{K}$, Carlsson A, Josefsson A. Caesarean section per se does not increase the risk of offspring developing type 1 diabetes: a Swedish population-based study. Diabetologia. 2015;58(11):2517-24.

23. Cardwell CR, Stene LC, Joner G, Davis EA, Cinek O, Rosenbauer $\mathrm{J}$, et al. Birthweight and the risk of childhood-onset type 1 diabetes: a meta-analysis of observational studies using individual patient data. Diabetologia. 2010;53(4):641-51.

24. Khashan AS, Kenny LC, Lundholm C, Kearney PM, Gong T, Mcnamee R, et al. Gestational age and birth weight and the risk of childhood type 1 diabetes: a population-based cohort and sibling design study. Diabetes Care. 2015;38(12):2308-15.

25. Li S, Zhang M, Tian H, Liu Z, Yin X, Xi B. Preterm birth and risk of type 1 and type 2 diabetes: systematic review and meta-analysis. Obes Rev. 2014;15(10):80411.

26. Bingley PJ, Douek IF, Rogers CA, Gale EA. Influence of maternal age at delivery and birth order on risk of type 1 diabetes in childhood: prospective population based family study. Bart's-Oxford Family Study Group. BMJ. 2000;321(7258):420-4.

27. van Belle TL, Coppieters KT, von Herrath MG. Type 1 diabetes: etiology, immunology, and therapeutic strategies. Physiol Rev. 2011(1);91:79-118.

28. Herold KC, Vignali DAA, Cooke A, Bluestone JA. Type 1 diabetes: translating mechanistic observations into effective clinical outcomes. Nat Rev Immunol. 2013;13(4):243-56.

29. Atkinson MA, Eisenbarth GS, Michels AW. Type 1 diabetes. Lancet. 2014;383(9911):69-82.

30. Mire-Sluis AR, Gaines Das R, Lernmark A. The World Health Organization international collaborative study 
for islet cell antibodies. Diabetologia. 2000;43(10):1282-92.

31. Bingley PJ, Bonifacio E, Mueller PW. Diabetes antibody standardization program: first assay proficiency evaluation. Diabetes. 2003;52(5):1128-36.

32. Baekkeskov S, Aanstoot HJ, Christgau S, Reetz A, Solimena M, Cascalho M. Identification of the $64 \mathrm{k}$ autoantigen in insulin-dependent diabetes as the GABA-synthesizing enzyme glutamic acid decarboxylase. Nature. 1990;347(6289):151-6.

33. Rhodes CJ, Alarcón C. What beta-cell defect could lead to hyperproinsulinemia in NIDDM? Some clues from recent advances made in understanding the proinsulin-processing mechanism. Diabetes. 1994;43(4):511-7.

34. Wenzlau JM, Juhl K, Yu L, Moua O, Sarkar SA, Gottlieb P, et al. The cation efflux transporter ZnT8 (Slc30a8) is a major autoantigen in human type 1 diabetes. Proc Natl Acad Sci USA 2007;104(43):17040-5.
35. Guarner F, Malagelada JR. Gut flora in health and disease. Lancet. 2003;361(9356):512-9.

36. Salminen S, Gibson GR, McCartney AL, Isolauri E. Influence of mode of delivery on gut microbiota composition in seven year old children. Gut. 2004;53(9):1388-9.

37. Grönlund MM, Lehtonen OP, Eerola E, Kero P. Fecal microflora in healthy infants born by different methods of delivery: permanent changes in intestinal flora after cesarean delivery. J Pediatr Gastroenterol Nutr. 1999;28(1):19-25.

38. Moreau MC, Ducluzeau R, Guy-Grand D, Muller MC. Increase in the population of duodenal immunoglobulin A plasmocytes in axenic mice associated with different living or dead bacterial strains of intestinal origin. Infect Immun. 1978;21(2):532-9.

39. Shroff KE, Meslin K, Cebra JJ. Commensal enteric bacteria engender a self-limiting humoral mucosal immune response while permanently colonizing the gut. Infect Immun. 1995;63(19):3904-13. 